\title{
KAJIAN SANITASI DAN HYGIENE PADA PENGASAPAN IKAN JULUNG- JULUNG (SAGELA) DI DESA PASALAE KECAMATAN GENTUMA RAYA KABUPATEN GORONTALO UTARA
}

\author{
Rahyuni Sy. Domili ${ }^{1}$, Titin Liana Febriyanti² \\ Program Studi Budidaya Perairan, Fakultas IImu-IImu Pertanian \\ Universitas Muhammadiyah Gorontalo \\ Email : rahyuni.domili@umgo.ac.id
}

\begin{abstract}
The aim of this research is to know the sanitation ascpect of Smoke Julung-julung fish processing (Sagela) in Pasalae Village, Gentuma Raya, Gorontalo Utara. This research was held ini Pasalae Village from August to December 2017. The type of research was used is a survey with respondents sample selected using random sampling technique, data collection by using questionnaires. Data analyzed by descriptive analysis. The result show that there are deviations on the sanitation dan hygiene conditions in smoke industry, which are five cricital deviation such as the layout, the employee hygiene, the prevent of cross contaminastion, the changing rooms, the shower dan toilet and pest control. For serious deviations is location and environment. Major deviation is waste handling. Two minor deviations are water security dan production equipments. From the description can concluded the smoke unit of sagela is not appropriate as a processing unit of fishery product in accordance with good standart
\end{abstract}

Keywords: Sanitasi, hygiene, Sagela

\section{PENDAHULUAN}

Ikan merupakan salah satu sumber pangan yang kaya protein yang sangat dibutuhkan oleh manusia, akan tetapi ikan juga memiliki kandungan air yang tinggi sehingga mudah rusak (Perishable food). Oleh karena itu dibutuhkan upaya untuk menghambat proses pembusukan dengan cara pengawetan dan pengolahan. Pengasapan merupakan salah satu cara pengolahan ikan yang berfungsi mengawetkan serta memberi aroma dengan cita rasa yang hasilkan.
Salah satu ikan yang ada di laut Gorontalo yaitu ikan Julung- julung atau Roa. Ikan Julung- julung ini oleh masyarakat Gorontalo diolah dengan cara pengasapan untuk memperpanjang masa simpannya. Roa atau Julung- julung asap (nama tradisionalnya adalah Sagela) adalah salah satu produk olahan yang dikonsumsi oleh masyarakat yang diolah secara tradisional yang dilakukan secara turun- temurun di Gorontalo. Menurut Patty et al., (2015), usaha pengolahan ikan roa asap yang dilakukan saat ini masih dilakukan 
dengan teknik yang sederhana dengan menggunakan kayu sebagai bahan bakarnya. Pengolahan ikan secara sederhana otomatis memiliki beberapa kekurangan seperti kurang terjaganya aspek sanitasi pada proses pengolahan. Aspek sanitasi merupakan salah satu yang sangat dipertimbangkan untuk menjamin mutu suatu produk olahan pangan.

Persaingan kualitas produk pangan di era globalisasi saat ini mendorong home industri untuk menghasilkan produk yang memenuhi standar keamanan pangan dan kepuasan konsumen. Untuk menghasilkan produk yang bersih, sehat dan aman diperlukan penerapan standar sanitasi dan hygiene di unit pengolahan pangan, khususnya dalam produksi ikan Julung- julung asap (Sagela).

Sanitasi didefinisikan sebagai usaha pencegahan penyakit dengan cara menghilangkan atau mengatur faktor- faktor lingkungan yang berkaitan dengan rantai perpindahan penyakit tersebut (Jenie, 1996).

Penerapan standar sanitasi di unit pengoalhan ikan saat ini sudah mengalami perkembangan dan beberapa sudah melakukan penelitian seperti Liufeto et all (2016), yag meneliti tentang Sanitation standard Operating Procedures dan Good Manufacturing Practice pengolahan ikan kayu di Kabupaten sikka. Selain itu Santoso juga telah melakukan penelitian tentang penerapan sanitasi dan mutu kemanan pengolahan ikan pindang ikan tongkol (Eutynunus affinis).

Prosedur- prosedur standar operasi sanitasi sangat perlu dalam penerapan perinsip pengelolaan lingkungan yang dilakukan melalui kegiatan sanitasi dan hygiene. Dalam hal ini SSOP menjadi program sanitasi wajib suatu industri untuk meningkatkan kualitas produk yang dihasilkan dan menjamin sistem keamanan produksi pangan. Dari uraian diatas kajian penerapan standar sanitasi pada pengolahan ikan asap julung- julung (Sagela) perlu dilakukan penelitian guna meningkatkan kualitas mutu produk olahan ikan asap Julungjulung (Sagela) yang diproduksi oleh tempat pengolahan yang ada di Desa Pasalae Kecamatan Gentuma Raya Kabupaten Gorontalo Utara.

\section{METODE PENELITIAN}

Lokasi penelitian ini yaitu Desa Pasalae Kecamtan Gentuma Raya Kabupaten Gorontalo utara. Populasi dalam penelitian ini adalah semua unit pengolahan yang memproduksi ikan Julung- julung asap (Sagela). Jumlah responden unit usaha yaitu sebanyak 4 orang pemilik usaha pengolahan ikan julung- julung asap (Sagela). Pengambilan sampel secara acak (random) dengan asumsi bahwa populasi dianggap homogen.

Jenis data yang digunakan adalah data primer dan sekunder. Data primer adalah data yang dikumpulkan melalui kuisioner dan wawancara langsung. Sementara data sekunder adalah data yang berasal dari instansi, buku, laporan hasil penelitian dan lain sebagainya. Model analisis yang digunakan adalah analisis deskriptif, yaitu analisis data dengan cara menggambarkan keadaan dan kondisi pengolahan ikan julung- julung asap. Data disajikan dalam bentuk histogram, tabel atau gambar kemudian diinterpretasikan (Hasan, 2008) 


\section{HASIL DAN PEMBAHASAN}

Keadaan Umum Lokasi Usaha

\section{Pengasapan Ikan Sagela}

Pengusaha pengasapan ikan Julung- julung asap (Sagela) di Desa Pasalae ada sebanyak empat orang. Berpendidikan SMP hingga SMU dengan pengalaman usaha sudah berjalan lebih dari 10 tahun bahkan ada yang sudah berjalan secara turun temurun selama 25 tahun. Lokasi tempat usaha sangat strategis untuk pasokan bahan baku dan jalur pemasaran karena terletak di pesisir pantai dan dekat dengan tempat pelelangan ikan. Bahan baku berupa ikan julung- julung diperoleh langsung dari nelayan di Desa Pasalae. Kebutuhan bahan baku rata- rata setiap pengolah sebanyak $200-300 \mathrm{~kg}$ per satu kali produksi, dengan kapasitas produksi 300 gepe sagela. Pemasaran ikan sagela yaitu seputaran pasar lokal, antar kabupaten hingga antar pulau yang sudah diolah menjadi sambal sagela.

Proses Pengasapan Ikan Julungjulung Asap (Sagela)

Proses pengasapan yang pertama yaitu penerimaan bahan baku yang diperoleh dari hasil tangkapan nelayan di Desa Pasalae. Ikan julungjulung tersebut diletakan dalam palka atau bak yang terbuat dari kayu. Ikan julung- julung kemudian dicuci untuk menghilangkan kotoran yang menempel pada ikan.

Tahap selanjutnya yaitu penjepitan bahan baku dengan menggunakan penjepit dari bambu dengan ukuran $70 \times 30 \mathrm{~cm}$. Setelah dijepit kemudian jepitan diikat dengan menggunakan bahan bambu yang basah agar hasil jepitan ikan pada bambu kuat dan tidak goyah saat proses pengasapan.

Proses ke tiga yaitu pengasapan yang dibagi menjadi dua tahap. Tahap pertama berlansung kurang lebih 8-10 jam dengan kisaran suhu 40-80 0C. Pengasapan yang ke dua berlangsung selama 5-6 jam dengan kisaran suhu 40 OC. Tujuan pengasapan pertama yaitu untuk mematangkan ikan serta mengurangi kadar air ikan. Sedangkan pengasapan ke dua yaitu pengasapan dingin bertujuan agar kandungan air yang masi tersisa benar- benar habis.

Sagela tidak memiliki kemasan khusus. Konsumen langsung membeli sagela yang masih terjepit bambu. Satu jepit sagela berisi 20 ekor ikan sagela. Sagela yang telah matang memiliki karakteristik kering, warna mengkilap keemasan, rasa gurih dengan cita rasa khas ikan asap.

\section{Penerapan Sanitasi pada Pengasapan} Ikan Julung- julung (Sagela)

Sanitasi pangan ditujukan untuk mencapai kebersihan yang prima dari tempat produksi, persiapan, penyimpanan dan penyajian makanan serta sanitasi pangan. Hal ini merupakan aspek yang sangat esensial dalam setiap kegiatan meyiapkan makanan khususnya cara penanganan pangan (Winarno dan Surono, 2004).

Standar baku sanitasi yang diamati di pengasapan ikan julungjulung (sagela) meliputi lokasi dan lingkungan, konstruksi bangunan, kemanan air, penanganan limbah, toilet, ruang pemeliharaan peralatan, wadah dan alat lain, control sanitasi, perlengkapan anti serangga dan binatang penggangu lainnya serta 
sanitasi proses produksi pengasapan ikan sagela.

1. Lingkungan dan lokasi

Berdasarkan pengamatan letak lokasi pengasapan ikan sagela berada didekat dari perkampungan padat penduduk, lingkungan kurang bersih dan berada pada daerah yang dekat dari pencemaran seperti yang berasal dari sumber sampah dan sistem saluran air yang tidak baik. Menurut Direktorat Mutu dan Pengolahan Hasil Perikanan (2007), bangunan unit pengolahan harus ditempatkan didaerah yang bebas dari kotoran yang bersifat bakteriologis, biologis, fisik dan kimia seperti di daerah rawa, rumput, semak yang memungkinkan tempat persembunyian binatang, pembuangan sampah, genangan air, perkampungan padat penduduk, daerah kering dan berdebu, industri, sehingga tidak menimbulkan penularan dan kontaminasi terhadap produk dan berbahaya bagi kesehatan masyarakat. Dari uraian diatas maka lokasi dan lingkungan termasuk penyimpangan yang serius.

2. Sanitasi Bangunan

Layout tempat pengasapan sagela semuanya berada di kawasan yang telah disetujui. Ruangan pengolahan ikan asap tidak dibersihkan atau disekat sehingga tidak dapat mencegah kontaminasi silang karena hanya ruangan untuk pengasapan saja yang memiliki bangunan tersendiri. Proses penerimaan bahan baku dan penjepitan ikan dilakukan diluar ruangan, sehingga hal ini berpotensi terjadinya penyimpangan kritis.

Dinding untuk ruangan pengasapan rata- rata terbuat dari beton ada juga yang terbuat dari anyaman bambu. Dindingnya bertekstur kasar dan hitam karena sering terkena asap saat proses pengasapan. Dinding yang terbuat dari anyaman bamboo tidak halus, ada celah dan lubang pertemuan Antara dinding dan lantai sulit dibersihkan.

Bangunan pengasapan ini terbuka dan tidak meiliki langit- langit. Langit- langit pada pengasapan ikan sagela tidak dirancang untuk mencegah akumulasi kotoran, mengurasi penguapan dan pertumbuhan jamur. Hal ini berpotesi terjadinya kontaminasi silang apabila ada debo atau kotoran yang terakumulasi. Ventilasi pada ruangan pengasapan ikan tergolong kecil akan tetapi pada bagian atap sudah terdapat lubang- lubang kecil yang bisa berfungsi sebagai ventilasi.

Lantai pada unit pengaspan hanya terbuat dari tanah yang memiliki permukaan kasar, retak dan sulit dibersihkan dan didesinfeksi.pintu ruangan pengolahan terbuat dari kayu yang tahan lama dan tahan korosi namun tidak menutup secara otomatis serta hanya satu pintu untuk keluar dan masuk keruang pengasapan, sehingga kontaminasi dari lingkungan luar kedalam ruangan pengasapan cukup besar. Menurut Lisyanti et al (2009), tata letak ruangan produksi dengan ruangan penerimaan bahan baku serta penyimpanan berdasarkan prosedur sanitasi yang baik harus terpisah sehingga mencegah terjadinya kontaminasi silang dan pekerja dapat melakukan pekerjaan secara saniter dan hygiene.

3. Hygiene Karyawan

Kontaminasi paling utama yang mungkin selama proses produksi yaitu berasal dari pekerja. Oleh karena itu kebersihan pekerja harus selalu dijaga agar tidak menyebabkan kontaminasi 
pada produk ikan sagela. Berdasarkan pengamatan pada unit produksi ikan sagela di Desa Pasalae rata- rata karyawan tidak mengenakan seragam hanya mengenakan pakaian yang biasa digunakan sehari- hari, tidak memakai sarung tangan ataupun penutup kepala. Selain itu tidak ada pelarangan bagi karyawan yang mengguanakn gelang, cincin, dan asesoris lain selama proses produksi. Penyimpangan tersebt merupakan penyimpangan kritis yang berpotensi menyebabkan kontaminasi silang dari karyawan ke produk yang dapat menyebabkan turunnya mutu ikan sagela yang dihasilkan.

Menurut Sertyawati dan Hartati (2005), karyawan adalah orang yang berhubungan dengan produk sejak persiapan hingga pengemasan. Pekerja memiliki aspek kontaminan yang tinggi melalui tangan, pakaian, rambut, dan keringat. Itulah mengapa pekerja pada industri pangan harus selalu bersih, tidak boleh ada luka dan wajib memakasi pakaian yang bersih dan rapi.

4. Sanitasi dan hygiene peralatan proses

$$
\text { Peralatan proses yang }
$$

digunakan pada pengasapan ikan sagela berdasarkan pengamatan terlihat terjaga kebersihannya. Peralatan yang digunakan seperti keranjang, baskom, dan perlatan lain dibersihkan setelah selesai produksi dengan cara dicuci dengan menggunakan sabun, kemudian dibilas dengan air biasa dan ditiriskan. potensi penyimpangan yang terjadi adalah penyimpangan minor. Kekurangan dari sanitasi peralatan proses yaitu proses pencucian peralatan seharusnya menggunakan air yang dicampur dengan klorin untuk membunuh mikroba dan mencegah terjadinya kontaminasi dari peralatan produk ke ikan sagela yang dihasilkan.

5. Keamanan Air

Air yang digunakan pada proses produksi ikan sagela rata- rata berasal dari PDAM, serta pasukan air untuk proses produksi mencukupi. Air tersebut digunakan untuk proses pencucian bahan baku dan membersihkan peralatan produksi. Secara keseluruhan sumber air yang digunakan untuk pengolahan ikan sagela sudah memenuhi standar yaitu tidak berwarna, tidak berbau dan tidak berasa, namun tetap harus dilakukan pemantauan secara terus terhadap kualitas air yang digunakan. Kemanan air termasuk penyimpangan minor. Menurut BSN (2011), bahwa air yag sapat digunakan dalam penanganan dan pengolahan pangan harus memenuhi persyaratan air minum, diantaranya tidak berbau, berwarna dan berasa.

6. Pencegahan Kontaminasi Silang Peralatan dan perlengkapan di unit pengasapan sagela ini belum tertata secara baik untuk mencegah kontaminasi silang dan menjamin kelancaran proses produksi. Proses pembersihan peralatan kotor dilakukan diarea yang sama dengan tempat penerimaan bahan baku, penyimpanan dan ruang produksi (penjepitan ikan Julung- julung) tanpa adanya dinding pembatas sehingga potensi terjadinya kontaminasi silang sangat besar.

Peralatan yang digunakan pada tiap tahapan produksi tidak diberi tanda dan tidak dibersihkan setiap kali digunakan pasa proses produksi sehingga meningkatkan peluang kontaminasi silang. Penyimpangan tersebut termasuk penyimpangan 
kritis. Menurut DKP (2007), konstruksi bangunan didesain tanpa memperhatikan uapaya pencegahan perpindahan kontaminan dari area yang kotor ke area yang bersih. Sehingga, peralatan yang berasal dari bagian penerimaan bahan baku berpotensi kontaminasi apabila digunakan pada area produksi. Misalnya penggunaan keranjang yang sama dibagian penerimaan bahan baku dan produksi.

\section{Penanganan Limbah}

Dari hasil pengamatan limbah di unit pengasapan sagela rata- rata langsung dibuang di dekat lokasi tempat pengolahan karena tidak adanya tempat khusus untuk pembuangan limbah. Limbah yang dihasilkan berupa limbah cair yaitu air untuk mencuci bahan baku yaitu julung- julung. Limbah ini mengandung darah dan potongan kecil ikan, kulit dan sisik.

Penanganan limbah dibutukan agar kandungan dalam limbah tidak mencemari lingkungan. Dari uraian tersebut penanganan limbah termasuk penyimpangan mayor. Menurut Nugroho (2017), tujuan dari penanganan limbah cair adalah untuk mengurangi kandungan bahan beracun atau bahaya yang ditimbulkan oleh limbah sehingga aman untuk dibuang kelingkungan.

8. Penyediaan dan pemeliharaan fasilitas sanitasi, cuci tangan dan toilet

Penyediaan dan pemeliharaan fasilitas sanitasi, cuci tangan dan toilet di tempat pengasapan ikan julung- julung di Desa Pasalae sesuai pengamatan rata- rata selama proses produksi pekerja tidak mencuci tangan setiap kali melakukan proses produksi. Ruang pengolahan tidak dilengkap dengan bak khusus cuci tangan, hanya berupa air kran yang terletak diluar ruangan pengasapan. Penyimpangan tersebut merupakan penyimpangan kritis.

Unit pengasapan ikan sagela di Desa Pasalae seluruhnya tidak meiliki fasilitas toilet khusus untuk pekerja, pekerja menggunakan toilet yang berada dirumah pemilik usaha atau dirumah masing- masing karena ratarata pekerjanta adalah masyarakat sekitar Desa Pasalae. Penyimpangan tersebut termasuk penyimpangan kritis.

9. Sanitasi pengendalian hama Upaya pengawasan, pencegahan dan pembasmian hama tidak dilakukan oleh unit pengasapan ikan julungjulung di Desa Pasalae. Hal ini dapat dilihat dari ruangan pengasapan yang terbuka dan pintu yang terbuat dari kayu, tidak adanya lampu pembunuh serangga pada ruangan pengolahan serta tidak dilakukan proses pembasmian hama secara berkala. Selain itu di unit pengolahan ini tidak menerapkan prosedur pest control untuk mencegah adanya hama penggangu. Penyimpangan tersebut merupakan penyimpangan kritis.

\section{KESIMPULAN}

Berdasarkan hasil penelitian yang telah dilakukan pada unit pengasapan ikan sagela di Desa Pasalae terdapat berbagai penyimpangan, yaitu penyimpangan kritis sebanyak lima diantaranya layout unit pengolahan, hygiene karyawan, pencegahan kontaminasi silang, ruang ganti, kamar mandi dan toilet serta pengawasan binatang/hama (pest control). Untuk penyimpangan serius yaitu lokasi dan lingkungan. 


\begin{abstract}
Penyimpangan mayor yaitu penanganan limbah. Dan penyimpangan minor ada dua yaitu keamanan air dan perlengkapan dan peralatan produksi. Berdasarkan hasil diatas maka pengasapan julungjulung (Sagela) di Desa Pasalae dikatakan tidak layak digunakan sebagai unit pengolahan produk perikanan yang sesuai dengan standar baku yang baik.
\end{abstract}

\section{DAFTAR PUSTAKA}

Badan Standarisasi Nasional. 2009. SNI 2725.3.2009. Sanitasi Pengolahan. Jakarta.

Direktorat Jendaral Pengolahan Dan Pemasaran Hasil Perikanan. 2007. Peraturan No. PER.001/DJ-P2HP/2007

Tentang Pedoman Teknis Penerapan Sistem Jaminan Mutu Dan Keamanan Hasil Perikanan. Jakarta

Direktorat Jendaral Pengolahan Dan Pemasaran Hasil Perikanan. Departemen Kelautan Dan Perikanan.

Departemen Kelautan Dan Perikanan (DKP). 2007. Keputusan Menteri Kelautan Dan Perikanan Republic Indonesia No. Kep. 01/Men/2007 Tentang Proses Produksi, Pengolahan Dan Distribusi. Jakarta: DKP.

Hasan. MI. 2008. Pokok- Pokok Materi Statistic 1 (Statistik Deskriptif), Edisi Kedua. Jakarta :Bumi Aksara.

Jenie, B.S.L.1996. Sanitasi Dalam Industry Pangan. Universitas Pangan Dan Gizi. Institute Pertania Bogor.
Lisyanti, Palupi NS, Kadarisman D. 2009. Evaluasi Penerapan Cara Produksi Yang Baik (GMP) Dan Penyusunan SSOP Industry Lidah Buaya PT. Libe Bumi Abadi. Jurnal Magister Professional Industry Kecil Menengah .

Luifeto, S, Et All. 2016. Kualitas Pengolahan Ikan Kayu. Prosiding Seminar Nasional Kelautan 2016.

Nugroho, P.J. 2017. Penerapan Sanitasi Unit Pengolahan Ikan Tuna Kaleng PT. Banyuwangi Cannery Indonesia. Kerja Praktek Program Studi Teknologi Pangan. Universitas Katolik Soegijapranata.

Patty, Et Al. 2015. Mutu Ikan Roa (Hemirhampus Sp) Asap Yang Adapa Di Pasar Tradisional Di Kota Manado Yang Disimpan Pada Suhu Ruang. Jurnal Median Teknologi Hasil Perikanan. Vo. 3, No. 2, Agustus 2015.

Santoso, K. 2010. Penerapan Sanitasi Dan Mutu Keamanan Pengolahan Pindang Ikan Tongkol (Euthynnus Affinis) Studi Kasus Di Pengolahan Hasil Perikanan Tradisional Muara Angke Jakarta Utara. Skripsi. Institute Pertanian Bogor.

Winarno Dan Suroso. 2004. Penanganan Ikan Segar. Pusat Penelitian Dan Pengembangan Perikanan.Jakarta. 